\title{
PEMANFAATAN PELEPAH KELAPA SAWIT TEROLAH SECARA AMONIASI DAN FERMENTASI TERHADAP PERFORMANS SAPI ACEH
}

\section{Utilization of Oil Palm Fronds Treated by Ammoniation and Fermentation on Performances of Aceh Cattle}

\author{
Jobel Sihombing1, R. Edhy Mirwandhono² dan Iskandar Sembiring ${ }^{2}$ \\ 1. Mahasiswa Program Studi Peternakan Fakultas Pertanian Universitas Sumatera Utara \\ 2. Staff Pengajar Program Studi Peternakan Fakultas Pertanian Universitas Sumatera Utara
}

\begin{abstract}
This study aims to determine the effect of the utilization of oil palm fronds treated by ammoniation and fermentation. Research conducted at the Laboratory Animal Sciences, Faculty of Agriculture, University of Sumatera utara for 4 months, starting in March - June 2015. This study used four male Aceh cattle and using a latin square design. The treatments were $P O=$ control, $P 1=$ ammoniation $($ urea $3 \%) P 2=$ fermented $($ biomol) $P 3=$ ammoniation + fermentation. The results showed that treatments had no significant effect on feed consumption, but convers had significant effect on body weight gain and feed converse ratio. Body weight gain (g/head/day) on treatments P0:P1:P2:P3. were 375,00 : 428,57: 571,43: 500,00, respectively. It is concluded that oil palm fronds treated by biomol show best result than other treatments.
\end{abstract}

Keywords : Palm frond, cattle Aceh, performance, physical processing, ammoniation, fermentation

\begin{abstract}
ABSTRAK
Penelitian ini bertujuan untuk mengetahui pengaruh pemanfaatan daun kelapa sawit terolah amoniasi dan fermentasi. Penelitian yang dilakukan di Laboratorium Biologi Ternak, Fakultas Pertanian, Universitas Sumatera Utara selama 4 bulan, mulai Maret-Juni 2015. Penelitian ini menggunakan empat sapi aceh jantan dan menggunakan desain bujur sangkar latin. Perlakuan P0 = kontrol, P1 = amoniasi (urea 3\%) P2 = fermentasi (biomol) P3 = amoniasi+fermentasi. Hasil penelitian menunjukkan bahwa perlakuan tidak berpengaruh signifikan tidak nyata terhadap konsumsi pakan, memiliki pengaruh yang signifikan terhadap kenaikan berat badan dan konversi pakan dan sebaliknya. Berat badan (g/ekor/hari) pada masing-masing perlakuan $\mathrm{P} 0=375,00: \mathrm{P} 1=428,57: \mathrm{P} 2=571,43: \mathrm{P} 3=500,00$,. Disimpulkan bahwa pelepah kelapa sawit fermentasi menggunakan biomol menunjukkan hasil terbaik dibandingkan perlakuan lainnya terhadap pertambahan bobot badan dan konversi pakan.
\end{abstract}

Kata kunci: Pelepah kelapa sawit, sapi Aceh, pengolahan fisik, amoniasi, fermentasi 


\section{PENDAHULUAN}

Akhir-akhir ini laju perkembangan dan pertumbuhan sapi aceh sangat lambat, sehingga terjadi penurunan populasi ternak mencapai 1.25\% (Dinas Kesehatah Hewan dan Peternakan Prov. Aceh, 2009). Hambatan utama bagi peternak khususnya dalam peningkatan populasi ternak yaitu terbatasnya pakan.Perluasan areal untuk penanaman rumput sebagai pakan ruminansia sangat sulit, karena alih fungsi lahan yang sangat tinggi. Mengingat sempitnya lahan pengembalaan, maka usaha pemanfaatan hasil (limbah) pertanian untuk pakan perlu dipadukan dengan bahan lain yang sampai saat ini belum maksimal digunakan sebagai bahan pakan.

Pakan merupakan salah satu faktor utama yang mempengaruhi sukses tidaknya usaha tersebut. Salah satu upaya dalam pengadaan pakan bagi ternak adalah memanfaatkan seoptimal mungkin lahan serta pemanfaatan limbah dan hasil samping komoditi perkebunan dan pertanian.

Salah satu sistem yang dapat mendukung pemenuhan kebutuhan pakan ternak adalah dengan pemanfaatan limbah kelapa sawit, diataranya pelepah kelapa sawit. Tanaman kelapa sawit merupakan tanaman yang berkembang pesat di Asia Tenggara termasuk Indonesia. Direktorat jendral perkebunan (2011) menyatakan luas perkebunan kelapa sawit di Indonesia mencapai 8.910.000 Ha dengan rincian luas areal perkebunan besar swasta 4.650.000 Ha, luas Perkebunan Rakyat 3.620.000 Ha, dan luas areal Perkebunan Besar Negara 640.000 Ha. Sedangkan di wilayah Sumatera Utara tingkat pertumbuhan produksi perkebunan kelapa sawit sangat signifikan dalam menghasilkan hasil samping kelapa sawit. Pada tahun 2011, luas areal perkebunan meningkat menjadi 1.175.078 Ha. Hal ini memberikan peluang bagi peternak dalam memanfaatkan hasil samping dari perkebunan kelapa sawit sebagai pakan alternatif.

Pelepah daun kelapa sawit merupakan hasil sampingan dari pemanenan buah kelapa sawit. Bila dilihat dari segi ketersediaannya maka pelepah dan daun kelapa sawit sangat potensial digunakan sebagai pakan ternak. Sesuai pernyataan Devendra (1990), siklus pemangkasan setiap 14 hari, tiap pemangkasan sekitar 3 pelepah daun dengan berat 1 pelepah mencapai $10 \mathrm{~kg}$. Satu Ha lahan ditanami sekitar 148 batang sehingga setiap 14 hari akan dihasilkan $\pm 4.440 \mathrm{~kg}$ atau $8.880 \mathrm{~kg} / \mathrm{bulan} / \mathrm{ha}$. Kandungan bahan kering dari pelepah daun sawit sebesar 35\% sehingga jumlah bahan kering pelepah sawit/bulan/ha sebesar $3.108 \mathrm{~kg}$.

Pelepah kelapa sawit memiliki kandungan serat kasar tinggi, protein rendah, serta tingkat kecernaan dan palatabilitas yang rendah. Hasil analisis yang telah dilakukan bahwa 
pelepah daun kelapa sawit mengandung 6,50\% PK, 32,55\% SK,4,47\% LK, 93,4\% BK dan 56,00\% TDN (Laboratorium Nutrisi Makanan Ternak, Program Studi Peternakan, FP USU, 2005).

Hasil analisis kimia menunjukkan bahwa daun sawit tersusun dari $70 \%$ serat kasar dan 22\% karbohidrat (berdasarkan bahan kering). Karakteristik ini juga menunjukkan bahwa daun sawit dapat diawetkan sebagai silase dan telah diperkirakan bahwa kecernaan bahan kering dapat meningkat $45 \%$ dengan pembuatan silase daun kelapa sawit (Hassan dan Ishida, 1992).

Permasalahan yang dihadapi dalam penggunaan limbah perkebunan kelapa sawit yang belum terolah, masih memiliki kandungan nutrisi yang rendah. Seperti tingginya kandungan serat kasar dan rendahnya nilai protein sehingga kercernaan menjadi rendah. Upaya yang dilakukan untuk mengatasi hal tersebut adalah dengan melakukan pengelolahan pakan secara amoniasi dan fermentasi.

Mathius dkk (2003) menyatakan bahwa pelepah kelapa sawit dapat dipergunakan sebagai sumber pengganti hijauan atau dapat diberikan dalam bentuk silase yang dikombinasikan dengan bahan lain. Pelepah kelapa sawit yang digunakan sebagai bahan pakan subtitusi rumput divariasikan pemberiannya sebesar 30-60 \% (Elisabeth dan Ginting, 2003). Pengolahan secara fisik dilakukan dengan mengubah ukuran dan bentuknya melalui proses pencacahan dan penggilingan. Pengolahan secara fementasi dilakukan dengan menggunakan mikroba dan fungi yang dapat merombak serat kasar menjadi komponen dan lebih sederhana sehingga kandungan nutrisi meningkat dan serat kasar semakin rendah. Pengolahan secara kimiawi dilakukan melalui proses amoniasi dengan penggunaan urea dalam bentuk padat. Pemberian pelepah kelapa sawit dapat memperbaiki performans pada sapi.

Atas dasar pemikiran ini maka perlu dilakukan suatu penelitian tentang pemanfaatan pelepah kelapa sawit terolah yang dalam penelititan ini dilakukan secara amoniasi dan fermentasi sebagai limbah perkebunan kelapa sawit sebagai pakan ternak.

\section{BAHAN DAN METODE PENELITIAN}

\section{Tempat dan Waktu Penelitian}

Penelitian dilaksanakan di Laboratorium Biologi Ternak Program Studi Peternakan Fakultas Pertanian Jalan Prof. Dr. Sofyan No.3 Universitas Sumatera Utara. Penelitian ini berlangsung selama 4 bulan, dimulai dari bulan maret sampai dengan bulan juni 2015 . 


\title{
Bahan dan Alat Penelitiaan
}

\section{Bahan}

Sapi Aceh yang digunakan sebagai objek penelitian sebanyak 4 ekor dengan bobot badan awal $96 \pm 8 \mathrm{~kg}$. Bahan pakan yang diberikan terdidari : pelepah daun kelapa sawit, bungkil inti sawit, biomol, molasses, dedak padi, ultra mineral, garam dan urea. Obat-obatan sperti obat cacing wormzol-B, rodalon sebagai desinfektan dan vitamin B-kompleks sebagai suplemen tambahan. Air minum diberi secara ad libitum.

Bahan yang digunakan untuk pembuatan amoniasi adalah : pelepah kelapa sawit, urea, dan air mineral. Bahan yang digunakan untuk fermentasi adalah : pelepah kelapa sawit, biomol, dan air mineral.

\begin{abstract}
Alat
Kandang individu 4 unit beserta perlengkapannya, tempat pakan sebagai wadah pakan. Timbangan sebagai alat untuk penimbangan bobot sapi, chopper sabagai alat pencincang pelepah kelapa sawit dan mixer sebagi alat pencampuran berbagai bahan pakan. Ember 4 buah sebagai wadah atau tempat air minum. Timbangan duduk kapasitas $500 \mathrm{~kg}$ sebagai alat penimbang bobot badan sapi. Timbangan dengan kapasitas $10 \mathrm{~kg}$ sebagai alat penimbang bahan pakan. Karung sebagai tempat bahan pakan, sapu dan sekop sebagai alat pembersih kandang, alat tulis sebagai alat pecatat data selama penelitian, kereta sorong sebagai alat pengangkut bahan pakan dan juga lampu sebagai alat penerangkandang.
\end{abstract}

\section{Metode Penelitian}

Rancangan penelitian yang digunakan adalah rancangan bujur sangkar latin. Perlakuan yang diteliti adalah :

P0 $=$ Pelepah Kelapa Sawit Terolah secara fisik

P1 = Pelepah Kelapa Sawit Terolah secara fisik + Amoniasi

P2 = Pelepah Kelapa Sawit Terolah secara fisik + Fermentasi

P3 = Pelepah Kelapa Sawit Terolah secara fisik + Amoniasi + Fermentasi 
Tabel 1. Formulasi ransum sapi

\begin{tabular}{lrrrr}
\hline \multicolumn{1}{c}{ Nama Bahan } & $\mathrm{P} 0(\%)$ & $\mathrm{P} 1(\%)$ & $\mathrm{P} 2(\%)$ & $\mathrm{P} 3(\%)$ \\
\hline Pelah sawit terolah secara fisik & 40 & - & - & - \\
Pelepah sawit terolah fisik + amoniasi & - & 40 & - & - \\
Pelepah sawit terolah fisik + fermentasi & - & - & 40 & - \\
Pelepah sawit terolah amoniasi + fermentasi & - & & - & 40 \\
Bungkil Inti Sawit & 37 & 37 & 37 & 37 \\
Dedak & 17 & 17 & 17 & 17 \\
Molases & 3 & 3 & 3 & 3 \\
Ultra Mineral & 1.5 & 1.5 & 1.5 & 1.5 \\
Garam & 1 & 1 & 1 & 1 \\
Urea & 0.5 & 0.5 & 0.5 & 0.5 \\
\hline Kandungan nutrisi & & & & \\
PK & 13.6407 & 13.9167 & 13.9327 & 13.9407 \\
SK & 25.4844 & 23.0284 & 20.4084 & 21.4884 \\
LK & 2.7324 & 2.7204 & 2.7124 & 2.6404 \\
TDN & 74.66 & 73.817 & 70.637 & 72.583 \\
\hline
\end{tabular}

\section{Proses Pembuatan Amoniasi Pelepah Kelapa Sawit}

Pelepah kelapa sawit dicoper, kemudian ditimbang, dan dikeringkan di bawah sinar matahari, stelah kering kemudian diperciki dengan larutan yang telah dicampur dengan urea 3\%, kemudian masukkan dalam plastik dan ikat sampai kedap udara, simpan selama 14 hari, kemudian diangin-anginkan Selma 2 jam, dan hasil amoniasi siap diberikan pada ternak.

\section{Proses Pembuatan Fermentasi Pelepah Kelapa Sawit}

Coper pelepah kelapa sawit, campurkan molasses $100 \mathrm{~g} / 1 \mathrm{~kg}$ pelepah dengan air kemudian siram pada pelepah. Taburkan biomol 35g/1kg pelepah secara merata. Masukkan kedalam plastik dan ikat sampai kedap udara. Simpan selama 7 hari, kemudian dianginkan selama 2 jam dan hasil fermentasi dapat diberikan kepada ternak.

\section{Parameter Penelitian}

\section{Konsumsi Pakan Bahan Kering (g)}

Tingkat konsumsi adalah jumlah pakan yang dikonsumsi oleh ternak, bila pakan tersebut diberi secara ad libitum. Kesehatan ternak juga dapat berpengaruh terhadap konsumsi pakan. Pada keadaan suhu lingkungan lebih tinggi dari yang dibutuhkan, nafsu 
makan akan berturun dan konsumsi air minum akan meningkat. Akhirnya, otot-otot daging dapat membesar dan daya tahanpun menurun (Hardjosworo dan Rukmiansih, 2001).

Konsumsi pakan dihitung berdasarkan selisih antara jumlah pakan yang diberikan dikurangi dengan jumlan pakan yang sisa.

Konsumsi BK $=($ Pakan diberi $(\mathrm{BK}))-($ Sisa pakan $(\mathrm{BK}))$

\section{Pertambahan Bobot Badan (g)}

Pertambahan berat badan dapat dikatakan pertumbuhan (Maynard dan Loosli., 1981). Parakkasi (1999), menyatakan pertumbuhan adalah pertambahan dalam bentuk dan berat jaringan-jaringan pembangun seperti urat daging, tulang, otak, jantung dan semua jaringan tubuh (kecuali jaringan lemak) serta alat-alat tubuh lainnya.

Pertambahan bobot badan yang di peroleh dengan menghitung selisih bobot badan akhir dengan selisih bobot awal. Penimbangan dilakukan setiap 1 minggu sekali.

Pertambahan Bobot Badan = Bobot Badan Akhir - Bobot Badan Awal

\section{Feed Convertion Ratio (FCR)}

Konversi pakan adalah perbandingan atau rasio antara jumlah pakan yang dikonsumsi oleh ternak dengan produk yang dihasilkan oleh ternak (Pane, 1986).

Konversi pakan merupakan ratio antara konsumsi pakan dengan pertambahan bobot badan.

Konversi Ransum $=$ Konsumsi Ransum

Pertambahan Bobot Badan

\section{HASIL DAN PEMBAHASAN}

\section{Konsumsi Pakan Bahan Kering}

Konsumsi pakan adalah kemampuan untuk menghabiskan sejumlah pakan yang diberikan secara ad libitum. Konsumsi pakan terus meningkat seiring dengan pertambahan kebutuhan zat-zat nutrisi oleh kebutuhan pokok dan pertumbuhan. Konsumsi pakan dapat dihitung dengan pengurangan jumlah pakan yang diberikan dengan sisa pakan yang tersedia. Pada penelitian ini rataan konsumsi pakan perlakuan dapat dilihat pada Tabel 2.

Berdasarkan Tabel 2 rataan konsumsi pakan tertinggi yaitu pada perlakuan P0: (pelepah terolah fisik) sebesar 4120,64 g/ekor/hari dan terendah pada perlakuan P2: (pelepah terolah fisik+fermentasi) sebesar 3886,39 g/ekor/hari. Konsumsi pakan ini lebih tinggi dari hasil penelitian Usman (2013), pada sapi aceh yang diberi hijauan 40\% dan konsentrat 60\% 
diperoleh 3610,00 g/ekor/hari. Hal ini disebabkan pemberian pakan perlakuan yang saya berikan dalam bentuk konsentrat.

Hasil analisis ragam menunjukkan bahwa pemberian pelepah kelapa sawit terolah amoniasi dan fermentasi memberikan pengaruh yang tidak nyata dalam konsumsi pakan $(\mathrm{P}>0.05)$, dapat diartikan bahwa respon sapi aceh terhadap palatabilitas antar perlakuan samasehingga sapi aceh suka pada semua jenis pakan perlakuan.

Hasil penelitian yang menunjukkan hasil respon sama disebabkan faktor dari ternak yaitu bobot badan yang sama, jenis sapi yang sama yaitu sapi aceh dan umur yang sama sehingga tingkat konsumsi menunjukkan hasil yang tidak signifikan. Faktor keadaan pakan pada penelitian ini yaitu tekstur pakan yang sama yaitu halus, sehingga tingkat palatabilitas antar pakan perlakuan sama. Faktor luar juga mempengaruhi seperti suhu dan kelembaban udara, karena sapi diletakkan pada kandang yang sama maka pengaruh lingkungan terhadap konsumsi pakan juga sama. Hal ini sesuai dengan pernyataan Sarwono dan Arianto (2007), yang menyatakan bahwa kemampuan sapi mengkonsumsi pakan sangat terbatas. Keterbatasan itu dipengaruhi oleh faktor ternak, keadaan pakan, dan faktor luar, seperti suhu dan kelembaban udara. Faktor yang mempengaruhi palatabilitas untuk ternak ruminansia adalah sifat fisik (rasa dan tekstur pakan), kandungan nutrisi dan kandungan kimia pakan.

\section{Pertambahan Bobot Badan}

Pertambahan bobot badan sapi aceh diperoleh dari hasil penimbangan bobot badan akhir dikurangi dengan bobot awal dalam satuan g/ekor/hari. Penimbangan dilakukan dengan selang waktu sekali dalam 7 hari. Pada penelitian ini rataan pertambahan bobot badan sapi aceh yang diperoleh selama penelitian dapat dilihat pada Tabel 2.

Tabel 2. Rekapitulasi hasil penelitian pemanfaatan pelepah kelapa sawit terolah amoniasi dan fermentasi terhadap konsumsi pakan, pertambahan bobot badan, dan konversi pakan sapi Aceh

\begin{tabular}{cccc}
\hline Perlakuan & $\begin{array}{c}\text { Konsumsi pakan } \\
\text { (g/ekor/hari) }\end{array}$ & $\begin{array}{c}\text { Pertambahan bobot } \\
\text { badan (g/ekor/hari) }\end{array}$ & $\begin{array}{c}\text { Konversi } \\
\text { Pakan }\end{array}$ \\
\hline P0 & $4120.64^{\text {tn }}$ & $375.00^{\mathrm{C}}$ & $11.44^{\mathrm{C}}$ \\
P1 & $4098.33^{\text {tn }}$ & $425.57^{\mathrm{C}}$ & $9.72^{\mathrm{C}}$ \\
P2 & $3886.39^{\text {tn }}$ & $571.43^{\mathrm{A}}$ & $6.83^{\mathrm{A}}$ \\
P3 & $4064.73^{\text {tn }}$ & $500.00^{\mathrm{B}}$ & $8.15^{\mathrm{B}}$ \\
\hline
\end{tabular}

\begin{aligned} \hline Keterangan : tn & Tidak nyata \\ $\mathrm{A}, \mathrm{B}, \mathrm{C}= &$ Superskrip yang berbeda pada kolom rataan menunjukkan berbeda \\ & sangat nyata $(\mathrm{P}<0,01)\end{aligned}$


Tabel 2 di atas menunjukkan bahwa rataan pertambahan bobot badan tertinggi terdapat pada perlakuan P2 (pepelah terolah fisik + fermentasi) yaitu sebesar 571.43 g/ekor/hari, sedangkan pertambahan bobot badan terendah terdapat pada perlakuan P0 (pelepah terolah fisik) yaitu sebesar $375.00 \mathrm{~g} / \mathrm{ekor} / \mathrm{hari}$.

Analisis ragam menunjukkan bahwa pemberian pelepah kelapa sawit terolah amoniasi dan fermentasi dalam bentuk pakan terhadap pertambahan bobot badan sapi berpengaruh sangat nyata $(\mathrm{P}<0.01)$. Hal ini disebabkan karena pertambahan bobot badan yang berbeda pada tiap perlakuan. Perbedaan ini terlihat pada perlakuan P2 ( 571,45 g/ekor/hari) lebih tinggi dibandingkan perlakuan P0 ( 375,00 g/ekor/hari), perlakuan P1 (428,57 g/ekor/hari) dan perlakuan P3 (500,00 g/ekor/hari).

Pemberian ransum pelepah kelapa sawit terolah fermentasi dapat meningkatkan pertambahan bobot badan sapi yang sangat nyata, untuk mengetahui perbedaan antara perlakuan dilakukan uji Duncan. Perlakuan P2 menunjukkan perbedaan dengan kenaikan rataan bobot badan lebih baik dibandingkan dengan perlakuan lainnya, sehingga pemanfaatan pelepah terolah fermentasi berpengaruh sangat nyata terhadap pertambahan bobot badan sapi. Hal ini terlihat dari perlakuan P2 dengan angka pertambahan bobot badan tertinggi sebesar 571.43 g/ekor/hari.

Perbedaan pertambahan bobot badan pada perlakuan P2 (Tabel 2) disebabkan karena serat kasar ransum dari perlakuan P2 (20.41\%) yang lebih rendah dibandingkan dengan ransum perlakuan P0 (25.48\%), perlakuan P1 (23.03\%) dan perlakuan P3 (21.48\%) dan juga karena proses fermentasi memiliki pengaruh positif terhadap kandungan nutrisi pakan karena fermentasi dapat menurunkan kandungan serat kasar pada pelepah sawit. Proses fermentasi memiliki pengaruh positif terhadap kualitas bahan pakan. Dan didukung oleh pernyataan Noviati (2002), menyatakan proses fermentasi dapat meningkatkan nilai gizi suatu bahan, akibat dari pemecahan senyawa kompleks menjadi senyawa yang lebih sederhana sehingga lebih mudah dicerna.

Tingginya pertambahan bobot badan dari perlakuan P2 juga disebabkan karena pakan hasil fermentasi yang memiliki kandungan nutrisi lebih tinggi, karena fermentasi menggunakan biomol menyebabkan pemanfaatan nutrisi pakan menjadi lebih baik. Hal ini sesuai dengan pernyataan Sony (2012), yang menyatakan bahwa apabila kualitas pakan rendah, kurang protein dan mineral, tinggi serat kasar dan lemak mungkin akan terbentuk 
kondisi ekosistem saluran cerna yang tidak seimbang, maka penggunaan biomol akan meningkatkan efektifitas pemanfaatan nutrient untuk menunjang produksi daging.

Pertambahan bobot badan penelitian ini lebih rendah dari hasil penelitian Usman (2013), pada sapi aceh yang diberi hijauan 40\% dan konsentrat 60\% diperoleh pertambahan bobot badan 610,00 g/ekor/hari. Konsumsi ransum yang tinggi tidak menjamin pertambahan bobot badan yang tinggi pula, hal ini sesuai dengan pendapat Azwani (2005), bahwa tidak semua ternak yang mengkonsumsi ransum yang lebih banyak, pertumbuhannya lebih tinggi dibandingkan dengan ternak yang mengkonsumsi ransum yang sedikit.

\section{Konversi Pakan}

Konversi pakan adalah banyaknya pakan yang dikonsumsi oleh ternak untuk menaikkan persatuan bobot badan ternak. Konversi pakan dapat dihitung berdasarkan total jumlah pakan yang dikonsumsi dibagi dengan pertambahan bobot badan sapi yang dihitung selama penelitian. Pada penelitian ini rataan konversi pakan selama penelitian dapat dilihat pada Tabel 2.

Tabel 2 di atas dapat dilihat bahwa rataan konversi pakan tertinggi terdapat pada perlakuan P0 (pelepah terolah fisik) sebesar 11.4473 dan rataan konversi terendah terdapat pada perlakuan P2 (pelepah terolah fisik+fermentasi) yaitu sebesar 6.8373.

Perlakuan P2 dengan tingkat konsumsi lebih rendah dan pertambahan bobot badan yang lebih tinggi dan tingkat konversi yang lebih rendah menunjukkan pemanfaatan pelepah kelapa sawit terolah fermentasi lebih efisien. Hal ini didukung oleh pernyataan Anggorodi (1999), yang menyatakan bahwa konversi pakan adalah indikator teknis yang dapat menggambarkan tingkat efesiensi penggunaan pakan, semakin rendah angka konversi pakan berarti semakin baik. Konversi pakan yang baik selama penelitian terdapat pada perlakuan P2 yaitu, 6.83 yang artinya adalah untuk menaikkan $1 \mathrm{~kg}$ bobot badan sapi aceh dibutuhkan pakan sebanyak 6-7 kg.

Pengaruh pemberian pelepah kelapa sawit terolah amoniasi dan fermentasi terhadap konversi pakan sapi dapat dilihat melalui analisis keragaman konversi pakan selama penelitian.Analisis keragaman konversi terolah amoniasi dan fermentasi memberikan pengaruh berbeda nyata $(\mathrm{P}<0.05)$ terhadap konversi pakan sapi.

Hasil uji lanjut Duncan menunjukkan bahwa konversi pakan yang dihasilkan berbeda nyata $(\mathrm{P}<0.05)$. Konversi pakan yang berbeda nyata tersebut disebabkan oleh adanya pertambahan berat badan yang berbeda nyata dan kualitas pakan yang berbeda. Hal ini sesuai 
dengan pendapat Rosida (2006), yang menyatakan bahwa konversi pakan sangat dipengaruhi oleh kondisi ternak, daya cerna, jenis kelamin, bangsa, penyakit, kualitas dan kuantitas pakan, juga faktor lingkungan yang tidak kalah penting.

Hal ini dikarenakan beberapa faktor yakni kualitas pakan, nilai kecernaan dan efisiensi pemanfaatan zat gizi dalam proses metabolisme di dalam jaringan tubuh ternak. Sama seperti halnya hasil pertambahan bobot badan, hal ini diasumsikan karena adanya perbedaan kandungan nutrisi pelepah daun kelapa sawit pada setiap pengolahan. Hal ini sesuai dengan pernyataan Pondet al. (1995), yang menyatakan bahwa konversi pakan pada ruminansia dipengaruhi oleh kualitas pakan, nilai kecernaan dan efisiensi pemanfaatan zat gizi dalam proses metabolisme didalam jaringan tubuh ternak. Makin baik kualitas pakan yang dikonsumsi ternak, akan diikuti oleh pertambahan bobot badan yang lebih tinggi dan makin efisien penggunaan pakannya.

Konversi pakan selama penelitian berkisar antara 6,83-11,44. Penelitian ini menyatakan hasil yang baik yaitu standar konversi yang baik adalah 8,56-13,29. Hal ini sesuai dengan pernyataan Siregar (2008), yang menyatakan bahwa konversi pakan untuk sapi yang baik adalah 8,56-13,29. Hasil penelititan ini lebih rendah dari penelitian Usman (2013), pada sapi aceh yang diberi hijauan $40 \%$ dan konsentrat $60 \%$ diperoleh konversi pakan $6 \pm$ 2.71. Hal ini diduga karena ransum yang dikonsumsi pada perlakuan penelitian saya sudah memenuhi

kebutuhan fisiologis ternak dengan kandungan protein dan energi yang tinggi, sehingga konversi ransum ternak menjadi rendah. Seperti yang diungkapkan oleh Maynard dan Loosly (1979) bahwa semakin tinggi nilai gizi dalam ransum, maka konversi ransum akan semakin rendah sehingga menunjukkan efisiensi penggunaan ransum menjadi lebih baik.

\section{KESIMPULAN}

Pengaruh pemberian pelepah kelapa sawit terolah fisik, amoniasi dan fermentasi, berpengaruh positif terhadap performans.Bahan pakan yang diolah dengan fisik+fermentasi (P2) memberikan pengaruh yang lebih baik, dibandingkan dengan pengolahan lainnya. 


\section{DAFTAR PUSTAKA}

Anggorodi, R. 1999. Ilmu Makanan Ternak Umum. Gramedia Jakarta.

Azwani, D. 2005. Pengaruh Pemberian Silase Rumput Gajah yang Difermentasi dengan Urea dan Molases terhadap Pertambahan Bobot Badan Kambing Jantan Lokal. Skripsi Fakultas Pertanian Universitas Syiah Kuala, Banda Aceh.

Direktorat Jenderal Perkebunan. 2011. Statistik Perkebunan KelapaSawit Indonesia. Jakarta.

Dinas Kesehatan Hewan dan Peternakan, 2009. Data Base Peternakan Provinsi Aceh. Banda Aceh

Devendra,C. 1990. Roughage Resources for Feeding in The Asean Region, The First Asean Workshop on Technology of Animal Feed Production Utility Food Waste Material. Malasya.

Elisabeth, J., dan S. P. Ginting. 2003. Pemanfaatan Hasil Samping Industri Kealapa Sawit Sebagai Bahan Pakan Ternak Sapi Potong. Prosidang Lokakarya Nasional :Sistem Integrasi Kelapa Sawit-Sapi. Bengkulu 9-10 September 2003. P. 110-119.

Hardjosworo, P.S dan Rukmiasih, M.S., 2000. Meningkatkan Produksi Daging. Penebar Swadaya, Yogyakarta.

Hassan, O.A. and M. Ishida. 1992. Status of utilization of selected fibrous crop residues and animal performance with special emphasis on processing of oil palm frond (OPF) for ruminant feed in Malaysia. Malaysia

Laboratorium Ilmu Makanan Ternak. 2005. Departemen Peternakan FP USU, Medan.

Mathius, I.W., D. Sitompul, RJ. Manurung dan Aani. 2003. Produk sampah tanaman dan pengolahan buahkelapasawit sebagai bahan dasar pakan komplit untuk sapi :suatu tinjauan. Prosiding Lokakarya Sistem Integrasi Kelapa Sawit Sapi. Bengkulu. 9-10 September 2003. Departemen Pertanian Bekerjasama dengan Pemerintah Provinsi Bengkulu dan Agricinal.

Maynard., L.A., J.K. dan Loosly., H.F. 1981. Animal Nutrition. McGraw-Hill Book Company, Inc.

Maynard, L.A., J.K. Loosly, H.F. Hinz and R.G. Wagner. 1979. Animal Nutrition. 7th ed. Publishing Company Ltd., New York.

Noviati A. 2002. Fermentasi Bahan Pakan Limbah Industri Pertanian dengan Menggunakan T.Harzianum [Skripsi]. Bogor :Jurusan Nutrisi dan Makanan Ternak Fakultas Peternakan IPB.

Parakkasi, A. 1999. Ilmu Nutrisi dan Makanan Ternak Ruminansia. Penerbit Universitas Indonesia. Jakarta.

Pane, I. 1986. Pemeliharaan Ternak Sapi. Gramedia Jakarta.

Pond, W.G., D.C. Church, and K.R. Pond, 1995. Basic Animal Nutrition and Feeding.Fourth edition. John Wiley \& Sons, New York.

Rosida, I. 2006. Analisis Potensi Sumber Daya Peternakan Kabupaten Tasikmalaya Sebagai Wilayah Pengembangan Sapi Potong. Fakultas Peternakan Institut Pertanian Bogor. 
Sarwono B. dan Arianto H. B, 2007. Penggemukan Sapi Potong Secara Cepat. PenebarSwadaya. Jakarta.

Situmorang, P,T,G, 2010. Pemanfaatan Pelepah Dan Daun Kelapa Sawit Fermentasi Dengan Aspergillus Niger Terhadap Pertambahan Bobot Badan Sapi Bali. USU-Press. Medan.

Siregar, S.B. 2008. Penggemukan Sapi. Penerbit Swadaya. Jakarta.

Sony. 2012. Material Safety Data Sheet (MSDS). Banyumas Raya. Bayumas.

Usman, Y., 2013. Evaluasi Pertambahan Bobot Badan Sapi Aceh Jantan yang Diberi Imbangan Antara Hijauan dan Konsentrat di Balai Pembibitan Ternak Unggul Indrapuri. Provinsi Aceh. Banda Aceh 